\title{
Risk Management of Potential Hazards Infections
}

\author{
S. Mugundan, S. Praveen Kumar, M. Vetrivel
}

\begin{abstract}
Nosocomial, or emergency clinic obtained, contaminations are viewed as the most well-known complexities influencing hospitalized patients. The point of this investigation was to recognize chance administration and survey potential clinic risks that may represent a danger to the wellbeing just as security and welfare of patients in an Iranian referral medical clinic. Obstructions to consistence and poor plan of offices, unreasonable rules and arrangements, absence of a structure for hazard the executives, inability to apply social change hypothesis, and lacking commitment and authorization by disease control work force feature the need of the board frameworks in contamination control in our clinic. What's more, observation and early detailing of diseases, assessment of hazard based intercessions, and generation of proof based rules in our nation are suggested.
\end{abstract}

Keywords: infection, nosocomial infection, risk management.

\section{INTRODUCTION}

Contamination anticipation and control (IPC) depends on the fitting administration frameworks, incorporating IPC into the board at all levels. Disease control gives a system to distinguishing proof of a risk and improvement of an activity intend to wipe out the peril or limit its impact through control measures [1,2]. Nosocomial, or clinic gained, contaminations are viewed as the most well-known complexities influencing hospitalized patients. The point of this investigation was to distinguish chance administration and audit potential emergency clinic perils which may represent a danger to the wellbeing just as security and welfare of patients in an Iranian referral medical clinic [3,4].

A few key components (e.g., administration, arrangement/strategy, instruction/preparing, reconnaissance, and checking of clinic cleanliness) have been distinguished as fundamental parts of an IPC program and ought to be tended to by all administrations (Figure 1). Administrative enthusiasm at a vital level to guarantee that compelling contamination control courses of action are set up just as supporting of senior administration and heads of clinical directorates is basic. Anticipation of nosocomial diseases is the obligation all things considered and administrations giving social insurance. The choice of fitting wellbeing related markers to screen are viewed as one of the most significant strides in plan and observation of contamination control. Vital leaders without learning or without frameworks to guarantee thought of disease control, and absence of

Revised Manuscript Received on July 22, 2019.

S. Mugundan*, Department of Management Studies, Bharath Institute of Higher Education and Research, Chennai, Tamilnadu, India

S. Praveen Kumar, Department of Management Studies, Bharath Institute of Higher Education and Research, Chennai, Tamilnadu, India

M. Vetrivel, Department of Management Studies, Bharath Institute of Higher Education and Research, Chennai, Tamilnadu, India checking of an assortment of procedures, results, and occasions can put patients in danger [5-7].

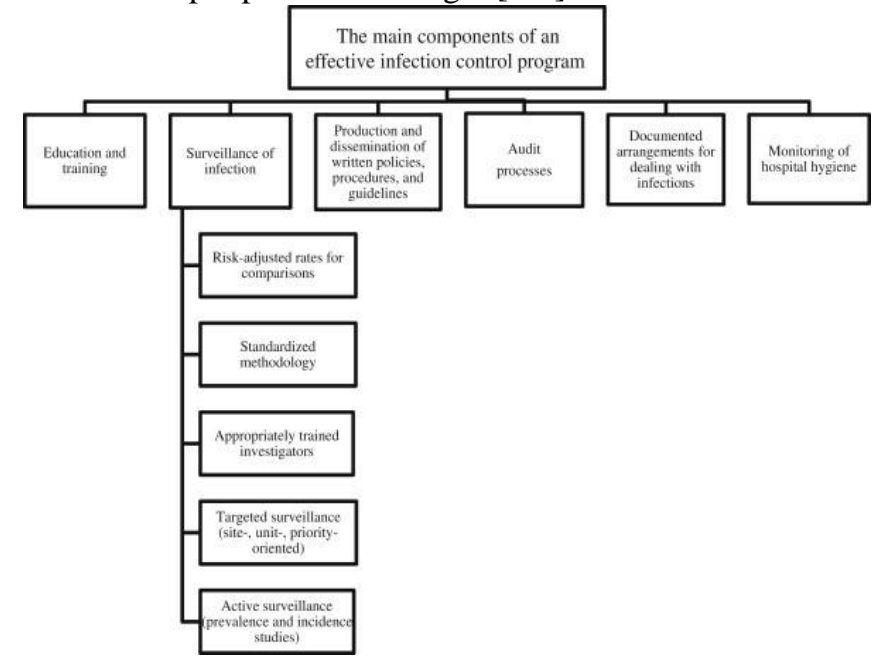

\section{THE FUNDAMENTAL SEGMENTS OF A POWERFUL DISEASE CONTROL PROGRAM.}

Procedures to forestall contaminations have been subdivided into a few gatherings (instruction based, process-based, and frameworks based). In any case, different intercessions, for example, "use anti-infection agents shrewdly" or "instruct and train staff" have been recommended, however the usage of them may be dubious and troublesome, especially in creating nations, for example, Iran $[8,9]$.

Presence of a composed arrangement inside the office to intently screen every one of them just as estimation and criticism of chose contamination control procedure consistence with disease control practices is important in our setting. Recognizable proof of hazard the board and the board of emergency clinic risks that may represent a danger to the wellbeing just as security and welfare of individuals ought to happen normally $[10,11]$.

Routine practices, for example, aseptic strategies, single-use gadgets, reprocessing of instruments and gear, anti-infection utilization, taking care of and utilization of blood and blood items, just as compelling work practices and methods, and ecological administration works on including the board of medical clinic major for the board of disease control [12-15].

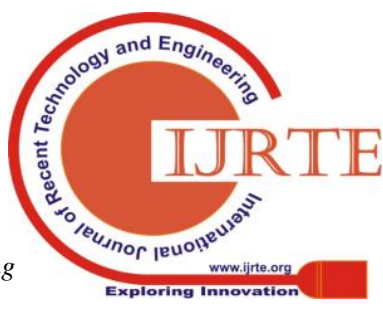




\section{THE WAY CORRESPONDENCE CHANNELS ARE UTILIZED INSIDE EMERGENCY CLINICS TO SPEAK WITH HCWS}

It has been accounted for that HCWs incline toward direct methods of correspondence (e.g., eye to eye and phone connection) as opposed to backhanded methods of correspondence (e.g., PC frameworks or arrangements). In spite of the fact that usage of approaches and rules is another method for correspondence, there are a few obstructions, for example, attempting to embrace practices that are sketched out in such records. In this manner, potential hindrances to embracing these elements ought to be considered practically speaking by rule or arrangement engineers [16-18].

\section{LEADERSHIP AND THE BOARD}

Ineffectual administration and initiative, insufficient cooperation and correspondence among staff, and absence of lucidity about duties are the fundamental things that elevate concerns, particularly in creating nations, for example, Iran.

As indicated by the consequences of the methodical survey, administration style strongly affects most patient results. Houser revealed that positive authority practices intervened by staff mastery and steadiness were related with decreased frequency of pneumonia [19-21].

\section{TEAMWORK AND MULTIDISCIPLINARY GROUP}

Wellbeing experts are required to secure general wellbeing by controlling disease. These duties ought to incorporate guaranteeing satisfactory disease control courses of action inside medical clinics [22]. A contamination control advisory group, which gives multidisciplinary info and participation, assumes a key job in each setting, especially for data sharing. The disease manage board is in charge of the advancement of approaches for the counteractive action and control of contamination by giving fundamental measures to contamination control; instruction and preparing of HCWs; distinguishing proof of perils; and improved practice to lessen plausible dangers at all degrees of the wellbeing office [23].

\section{BEHAVIORAL CHANGE}

One of the most testing impediments in certain settings particularly in creating nations, for example, Iran, is social change. Disease hazard has been demonstrated to be emphatically identified with staffing levels and staff preparing. In spite of instructive endeavors, cross-disease of patients by HCWs whose hands are sullied may happen as a result of an absence of adherence to gauges [24].

\section{TRANSMISSION-BASED STRATEGIES}

Transmission-based safeguards are viewed as an imperative factor identified with contamination control rehearses. Persistent growth visiting may be a major risk factor in microorganism dispersal and nosocomial contamination in our clinic. Our previous findings suggest that cross-transmission for $\mathrm{P}$. aeruginosa would be a major colonization or contamination course. The outcomes demonstrated impressive cross-transmission of $\mathrm{P}$. aeruginosa among patients in a single ward as well as among those from various wards. The spread of microbes around the medical clinic can be caused by the lack of methodologies centered on frameworks, lawful methodology for disease command, and the risk to the board in our emergency clinic $[25,26]$.

Arrangement of patients with illnesses, for example, cystic fibrosis (CF) in a solitary room wherein the air is released outside or extraordinarily separated before when it is circled to different regions of the social insurance office is another hazard for cross-defilement of nature and can give chances to transmission of contamination. In our emergency clinic, cross-disease among patients with $\mathrm{CF}$ and those without happened as a result of an absence of isolation strategies and essential cleanliness measures. Since the emergency unit in our middle concedes an assortment of patients, incorporating those with $\mathrm{CF}$, transmission of microscopic organisms is plausible. Subsequently, composed arrangements and strategies that are refreshed routinely should be created.

Also, airborne infection of microorganisms from ecological surfaces can happen because of insufficient cleaning, purification, or disinfection. In this manner, strategies must be set up that indicate the recurrence of cleaning and all reused therapeutic gadgets [27, 28]. Routine cleaning of work surfaces.

\section{RESULTS}

Another factor identifying with disease control the executives is the bed turnover interim. In emergency clinics, for example, our setting with outstanding tasks at hand related with high turnover. Be that as it may, absence of appropriate contamination control and advancement of nosocomial diseases may prompt extra days in the emergency clinic and noteworthy mortality. The estimation of contamination related with human services in created wellbeing frameworks in districts, for example, Australia, Denmark, England, France, The USA shift somewhere in the range of $4 \%$ and $10 \%$ [29].

In this way, explicit approaches and practices to limit nosocomial contaminations must be built up. Furthermore, inspecting and refreshing just as consistence checking ought to be done consistently in our medical clinic.

\section{DISCUSSION}

Contamination control groups ought to work together with other applicable staff to screen the execution and adequacy of the medical clinic's normal methods on cleansing or sanitization of hardware, enhanced clinical waste transfer. A natural review cycle including recognizing the issue, applicable instruction and preparing [30].

\section{CONCLUSION}

For the most part, the spread of MRSA and VRE occurs through transient carriage on HCW's hands. As a consequence of the elevated rate of MRSA and VRE disengages, aseptic techniques need to be polished in our medical clinic, for instance, waterless germ-free hand runs and the use of smooth dresses and gloves. Moreover, hands must be clean in the wake of washing in light of the fact that the lingering dampness left on the hands may harbor microscopic organisms [31-33]. 
As indicated by the Cochrane deliberate survey of 118 preliminaries to assess the impacts of review and criticism on the acts of HCWs, for example, anti-infection endorsing etc.

\section{REFERENCES}

[1] BharthVajan R., Ramachandran S.,Psychographic dimensions of training,2016,International Journal of Pharmacy and Technology,V-8,I-4,P-23727-23729

[2] Balakrishnan P., Bharthvajan R.,A study on human resource planning in hospitals in Chennai City,2014,International Journal of Applied Engineering Research,V-9,I-22,P-7503-7507

[3] Priyadarsini P., Bharthvajan R.,Role of emotional intelligence training programme in reducing the stress of the nurses,2014,International Journal of Applied Engineering Research,V-9,I-22,P-7411-7421

[4] Kerinab Beenu G., Bharthvajan R.,Empirical analysis on the cosmetic buying behavior of young women in South India,2014,International Journal of Applied Engineering Research,V-9,I-22,P-7361-7366

[5] Balakrishnan P., Bharthvajan R.,Whistling in the wind,2014,International Journal of Applied Engineering Research,V-9,I-22,P-7586-7593

[6] Krishnan B., Peter M.,Health hazards of Indian Bpo employee-an alarming issue,2014,International Journal of Applied Engineering Research,V-9,I-22,P-7336-7341

[7] Kerinab Beenu G.H., Peter M.,Role of insurance in economic development,2014,International Journal of Applied Engineering Research,V-9,I-22,P-7532-7539

[8] Balakrishnan P., Peter M., Priyadarsini P.,Efficiency of safety measures for wellbeing of employees in manufacturing industry,2014,International Journal of Applied Engineering Research,V-9,I-22,P-7376-7382

[9] Anbarasi M., Praveen Kumar S.,Online sales promotions of herbal products and its effectiveness towards tanisha.com,2019,Indian Journal of Public Health Research and Development,V-10,I-1,P-195-200

[10] Anbarasi M., Praveen Kumar S.,Various online marketing and promotions strategies to improve the validation towards the organic products in the pharmaceutical sectors,2019,Indian Journal of Public Health Research and Development,V-10,I-1,P-263-269

[11] Loganathan R., Praveen Kumar S.,Grievance handling a key factor for solving issues of employees in an organization,2014,International Journal of Applied Engineering Research,V-9,I-22,P-7483-7491

[12] Loganathan R., Praveen Kumar S.,Study on preference of private label brands in super and Hypermarkets,2014,International Journal of Applied Engineering Research,V-9,I-22,P-7327-7335

[13] Smitha M., Praveen Kumar S.,Understanding stress and its managementamong the nurses in Chennai city,2014,International Journal of Applied Engineering Research,V-9,I-22,P-7560-7565

[14] Kerinab Beenu G.H., Praveen Kumar S.,A study on the investment behavior of Chennai investors in mutual fund schemes,2014,International Journal of Applied Engineering Research,V-9,I-22,P-7520-7525

[15] Loganathan R., Praveen Kumar S.,Retention strategies key for organizational productivity,2014,International Journal of Applied Engineering Research,V-9,I-22,P-7443-7447

[16] Pavithra J., Ganesan M., Brindha G.,State wise analysis of microfinance sector in India,2016,International Journal of Pharmacy and Technology,V-8,I-4,P-23417-23432

[17] Pavithra J., Ganesan M.,A comparative study on microfinance in India and abroad,2016,International Journal of Applied Business and Economic Research,V-14,I-8,P-5471-5476

[18] Pavithra J., Ganesan M.,A study on awareness and impact of micro-financial schemes,2016,International Journal of Applied Business and Economic Research,V-14,I-8,P-5449-5460

[19] Senthilmurugan P., Pavithra J.,Consumer preference towards organised retailing with reference to Big Bazaar,2014,International Journal of Applied Engineering Research,V-9,I-22,P-7469-7475

[20] Senthilmurugan P., Pavithra J.,Implication of social media marketing in growing healthcare industry,2014,International Journal of Applied Engineering Research,V-9,I-22,P-7448-7456

[21] Loganathan R., Pavithra J.,Consumer perception towards private label brand over other brands in super markets and hypermarkets,2014,International Journal of Applied Engineering Research,V-9,I-22,P-7355-7360

[22] Kerinab Beenu G., Pavithra J.,Tradeâ€"off between liquidity and profitability in logistics industry,2014,International Journal of Applied Engineering Research,V-9,I-22,P-7398-7401
[23] Kerinab Beenu G., Pavithra J.,A study on the prospective consumerâ€ $€^{\mathrm{TM}_{\mathrm{S}}}$ perception towards utility cars in Chennai city,2014,International Journal of Applied Engineering Research,V-9,I-22,P-7526-7531

[24] Pavithra J., Dilli Babu P., Ambuli T.V.,A study on budgetary control at Maruti Service Masters, Chennai,2014,International Journal of Applied Business and Economic Research,V-12,I-2,P-151-161

[25] Pavithra J., Dilli Babu P., Ambuli T.V.,A study on customer satisfaction of retro Garments Pvt Ltd, Chennai,2014,International Journal of Applied Business and Economic Research,V-12,I-2,P-381-391

[26] Kerinab Beenu G.H., Pavithra J., Senthilmurugan P.,A study on the influence of promotional activities for TATA ARIA among consumers in Chennai,2014,International Journal of Applied Engineering Research,V-9,I-22,P-7572-7578

[27] Vijayaragavan S.P.,An investigative expert that's general FBG sensors,International Journal of Mechanical Engineering and Technology,V-8,I-8,PP-1500-1505,Y-2017

[28] Vijayaragavan S.P.,Equalization routing protocol for Wi-Fi sensor strategy,International Journal of Mechanical Engineering and Technology,V-8,I-8,PP-1662-1666,Y-2017

[29] Karthik B., Kiran Kumar T.V.U., Vijayaragavan P., Bharath Kumaran E.,Design of a digital PLL using 0.35 $\hat{\mathrm{I}}^{1 / 4 \mathrm{~m}}$ CMOS technology,Middle East Journal of Scientific Research,V-18,I-12,PP-1803-1806,Y-2013

[30] Kanniga E., Selvaramarathnam K., Sundararajan M.,Kandigital bike operating system,Middle - East Journal of Scientific Research,V

[31] Jasmin M., Vigneshwaran T., Beulah Hemalatha S.,Design of power aware on chip embedded memory based FSM encoding in FPGA,International Journal of Applied Engineering Research,V-10,I-2,PP-4487-4496,Y-2015

[32] Jasmin M.,Optimization techniques for low power VLSI circuits,Middle - East Journal of Scientific Research,V-20,I-9,PP-1082-1087,Y-2014

[33] Jasmin M., Vigneswaran T.,Fuzzy controller for error control of on Chip communication,2017 International Conference on Algorithms, Methodology, Models and Applications in Emerging Technologies, ICAMMAET 2017,V-2017-January,I-,PP-1-5,Y-2017

\section{AUTHORS PROFILE}

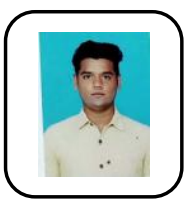

S. Mugundan, Student, Department of Management Studies, Bharath Institute of Higher Education and Research, Chennai, India

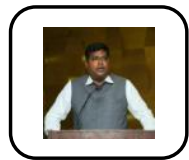

S. Praveen Kumar, Associate Professor, Departmen of Management Studies, Bharath Institute of Higher Education and Research, Chennai, India

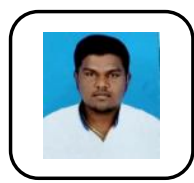

M. Vetrivel, Student, Department of Managemen Studies, Bharath Institute of Higher Education and Research, Chennai, India 